\title{
Amino acid requirements in children and the elderly population
}

\author{
Raja R. Pillai and Anura V. Kurpad* \\ St. John's Research Institute, Bangalore, India \\ (Submitted 30 August 2011 - Final revision received 5 November 2011 - Accepted 13 December 2011)
}

\begin{abstract}
The factorial approach is used to measure the dietary indispensable amino acid (IAA) requirements in children, although recent measurements based on the indicator amino acid oxidation (IAAO) method have begun to generate more direct evidence. Difficulties with the factorial method are that it depends on accurate estimates of the maintenance protein requirement, as well as of protein deposition during growth. Also, a value for the efficiency of utilizing dietary protein for deposition has to be selected, based on published Nitrogen (N) balance studies. In the recent $2007 \mathrm{WHO} / \mathrm{FAO} / \mathrm{UNU}$ report, the amino acid requirement pattern for infants was taken to be similar to the amino acid composition of breast milk. For pre-school and older children, the factorial method gave values for the scoring pattern of protein that were fairly close to the earlier $1985 \mathrm{WHO} / \mathrm{FAO} / \mathrm{UNU}$ report for children, since growth progressively became a smaller component of the factorial calculation as age progressed. However, given that there are several assumptions in the derivation of factorial estimates, direct experimental measurements of the amino acid requirement are desirable. The IAAO method, as it is non-invasive, as made it possible to measure the IAA requirements in children. Over the last decade, some of the IAA requirements have been determined by using the IAAO method in healthy school age children; however, the data on IAA requirements in developing country populations are still being conducted. In the elderly, there are not enough data to make a separate recommendation for IAA requirements from that of adults.
\end{abstract}

\section{Key words: Amino acid requirement: isotopes: children: elderly}

\section{Introduction}

Current estimates of dietary IAA requirements in children are derived based on a factorial computation due to the lack of enough direct experimental data. For a variety of reasons recommended amino acid requirement values for children were calculated using the factorial method and were derived from earlier $\mathrm{N}$ balance studies and from adult values. In general, the $\mathrm{N}$ balance studies have numerous shortcomings due to various practical and data interpretation limitations, which have been widely discussed ${ }^{(1-7)}$. Recent recommended amino acid requirements in children derived by the factorial $\operatorname{method}^{(7)}$ considered various factors in developing the new recommendations. Difficulties with the factorial method are the accurate measurement of growth and maintenance requirements and therefore, direct experimental determinations are desirable. The isotope-based methods have begun to yield data in children with newer short term, noninvasive techniques.

\section{Amino acid requirements in children based on the factorial approach}

The factorial approach, based on the maintenance and growth components of the protein requirement, was used to estimate the current $\mathrm{WHO} / \mathrm{FAO} / \mathrm{UNU}^{(7)}$ amino acid requirement values. These were based on the rates of growth based on protein deposition for children of different age groups, the amino acid composition of whole-body protein, as well as the efficiency of dietary protein utilization. Therefore, the requirements were the sum of amino acids needed for maintenance (i.e. the maintenance protein requirement $(\mathrm{g} / \mathrm{kg} / \mathrm{d})$ ) multiplied by the adult amino acid scoring pattern ( $\mathrm{mg} / \mathrm{g}$ protein), plus growth (tissue protein deposition rates in $\mathrm{g} / \mathrm{kg} / \mathrm{d}$ ) multiplied by the assumed human tissue amino acid pattern $(\mathrm{mg} / \mathrm{g}$ protein), adjusted for an efficiency of deposition of 0.58 . The factorial approach depends heavily therefore, on the accurate estimation of the maintenance protein requirement, as well as of protein deposition during growth. In addition, a value for the efficiency of utilizing dietary protein for deposition also had to be selected, based on the $\mathrm{N}$ balance studies that were available.

In the case of the infant up to the age of 6 months, the amino acid content of breast milk is recognized as the best estimate of amino acid requirements. The average essential amino acid composition of mixed human milk proteins is given in Table 1, averaged from 3 sources by WHO/FAO/ $\mathrm{UNU}^{(7)}$. It must be recognized that this pattern of amino acids may provide an intake that is in excess of the infant's needs. 
Table 1. Amino acid composition of mixed human milk proteins (WHO/FAO/UNU, 2007)

\begin{tabular}{lc}
\hline Amino acid & mg amino acid/g total milk protein \\
\hline Lysine & 69 \\
Threonine & 44 \\
Methionine & 16 \\
Leucine & 96 \\
Isoleucine & 55 \\
Valine & 55 \\
Phenylalanine & 42 \\
Tryptophan & 17 \\
Histidine & 21 \\
\hline
\end{tabular}

In the case of older children, no satisfactory experimental data were available at the time to determine the amino acid requirement, and therefore, the factorial approach, stated above, was used. A brief description of the procedure used to decide on the maintenance and growth deposition requirement of protein is necessary as these are critical to the factorial method. First, for the derivation of the maintenance requirement, the current WHO/FAO/UNU Report ${ }^{(7)}$ used the results from ten studies that examined the relationship between protein intake and $\mathrm{N}$ balance both above and below maintenance. Fitting these data to a linear model yielded a line with a slope (or an efficiency of utilization) of 0.58 , and an intercept (the obligatory $\mathrm{N}$ loss when $\mathrm{N}$ intake was zero) of $58 \mathrm{mg} / \mathrm{kg} / \mathrm{d}$. For studies that used milk or egg based protein, the slope was higher, at 0.66 . From the regression of $\mathrm{N}$ balance on $\mathrm{N}$ intake, a value for the maintenance requirement of $\mathrm{N}$ could be obtained by calculating the $\mathrm{N}$ intake required for a zero $\mathrm{N}$ balance. The mean value for the maintenance requirement was $108-110 \mathrm{mg} \mathrm{N} / \mathrm{kg}$ /day over all studies, but lower at $93 \mathrm{mg} \mathrm{N} / \mathrm{kg} /$ day in the animal protein (milk/egg) intake studies. This lower maintenance requirement could have been because of the better digestibility of the animal proteins, as well as a better efficiency of utilization (0.66 vs. 0.58 in the mixed protein intake diets). Therefore, in the $\mathrm{WHO} / \mathrm{FAO} / \mathrm{UNU}$ Report ${ }^{7}$ the value chosen for infants up to 6 months of age was based on the maintenance value for the milk/egg protein diets, which was $93 \mathrm{mg} \mathrm{N} / \mathrm{kg} /$ day. This works out to a protein intake of $0.58 \mathrm{~g}$ protein $/ \mathrm{kg} /$ day. For children with ages greater than 6 months, the maintenance value chosen was $110 \mathrm{mg} \mathrm{N} / \mathrm{kg} /$ day, which was the mean maintenance value from all the $\mathrm{N}$ balance studies quoted above. This works out to $0.68 \mathrm{~g}$ protein $/ \mathrm{kg} /$ day, and ultimately, since this was so close to the adult maintenance value, the maintenance value for children above 6 months of age was set at $0.66 \mathrm{~g}$ protein $/ \mathrm{kg} /$ day, or similar to that in adults. In addition, there was no a priori reason to think that the maintenance value in children would differ from that of adults, although the efficiency of utilization may change as growth occurs. Therefore, the critical change for the maintenance requirement in this growth model occurs at 6 months of age, which also matches the time at which the feeding of the infant changes to mixed diets with weaning.

Second, for measuring protein deposited during growth, the average daily rates of protein deposited were derived from the measurement of whole body potassium ${ }^{(8,9)}$. In a longitudinal study, Butte et al ${ }^{(9)}$ followed 76 individual infants from birth to 2 years with measurements every three months. The total protein data of each of the individuals were fitted to individual quadratic equations to estimate the protein deposited $/ \mathrm{kg}$ body weight/day. The protein deposition of children (4-18y) were reported in a study by Ellis et al. ${ }^{(8)}$ in a cross sectional study. A single model was fitted to the entire data set for each gender and the protein deposition data (yearly cohort averages) were fitted to a single cubic curve for each gender, and the curves were differentiated to give protein deposition rate estimates. The body weight data were also fitted to curves for each gender, and the ratio of these two functions (adjusted to give daily values) gave estimates of protein deposition per kg body weight/day. Since there were now 2 different datasets for protein deposition at different ages, a quadratic equation was used to interpolate data between the two data sets for the missing ages between 2 and 4 years ${ }^{(7)}$.

If the maintenance and growth requirements for protein were known, as detailed above, then for each dietary IAA, the content in the amino acid composition of the requirement pattern for maintenance in adults was multiplied into the maintenance requirement for protein. For protein deposition during growth, the dietary IAA content based on the amino acid composition of mixed tissue protein ${ }^{(10)}$ was used to multiply the protein deposited with growth (adjusted for efficiency of utilization of dietary protein), for each amino acid. The sum of the maintenance and growth deposition amino acid requirements was taken as the estimated average requirement for each amino acid. This factorial approach is shown in Table 2. The amino acid scoring pattern for this requirement is given in Table 3. This is in contrast to the 1985 FAO/ WHO/UNU consultation ${ }^{(6)}$, where the scoring pattern for pre-school children was used for all ages. In general, the

Table 2. Amino acid requirements of children determined using the factorial approach (WHO/FAO/UNU, 2007)

\begin{tabular}{|c|c|c|c|c|c|c|c|c|c|c|c|}
\hline \multirow[b]{2}{*}{ Age $(y)$} & \multicolumn{2}{|c|}{ Protein requirement $(\mathrm{g} / \mathrm{kg} / \mathrm{d})$} & \multicolumn{9}{|c|}{ Amino Acid requirement $(\mathrm{mg} / \mathrm{kg} / \mathrm{d})$} \\
\hline & Maintenance & Growth & His & lle & Leu & Lys & SAA & AAA & Thr & Trp & Val \\
\hline 0.5 & 0.66 & 0.46 & 22 & 36 & 73 & 64 & 31 & 59 & 34 & 9.5 & 49 \\
\hline $1-2$ & 0.66 & 0.20 & 15 & 27 & 54 & 45 & 22 & 40 & 23 & $6 \cdot 4$ & 36 \\
\hline $3-10$ & 0.66 & 0.07 & 12 & 23 & 44 & 35 & 18 & 30 & 18 & $4 \cdot 8$ & 29 \\
\hline $11-14$ & 0.66 & 0.07 & 12 & 22 & 44 & 35 & 17 & 30 & 18 & $4 \cdot 8$ & 29 \\
\hline $15-18$ & 0.66 & 0.04 & 11 & 21 & 42 & 33 & 16 & 28 & 17 & 4.5 & 28 \\
\hline
\end{tabular}

His: Histidine; Ile - Isoleucine; Leu - Leucine; Lys - Lysine; SAA - Sulphur Amino Acids; AAA - Aromatic Amino Acids; Thr - Threonine; Trp - Tryptophan and Val - Valine. 
Table 3. Amino acid scoring pattern for children (mg/g protein) ${ }^{\mathrm{a}}$ (WHO/FAO/UNU, 2007)

\begin{tabular}{lccccccccc}
\hline Age $(\mathrm{yrs})$ & His & Ile & Leu & Lys & SAA & AAA & Thr & Trp & Val \\
\hline 0.5 & 20 & 32 & 66 & 57 & 28 & 52 & 31 & $8 \cdot 5$ & 43 \\
$1-2$ & 18 & 31 & 63 & 52 & 26 & 46 & 27 & $7 \cdot 4$ & 42 \\
$3-10$ & 16 & 31 & 61 & 48 & 24 & 41 & 25 & $6 \cdot 6$ & 40 \\
$11-14$ & 16 & 30 & 60 & 48 & 23 & 41 & 25 & $6 \cdot 5$ & 40 \\
$15-18$ & 16 & 30 & 60 & 47 & 23 & 40 & 24 & $6 \cdot 3$ & 40 \\
\hline
\end{tabular}

His: Histidine; lle - Isoleucine; Leu - Leucine; Lys - Lysine; SAA - Sulphur Amino Acids; AAA - Aromatic Amino Acids; Thr - Threonine; Trp - Tryptophan and Val - Valine.

a - amino acid requirement/protein requirement for the selected age group

new $\mathrm{FAO} / \mathrm{WHO} / \mathrm{UNU}^{(7)}$ estimates of requirements are lower than the earlier values that were used for the pre-school child.

\section{Amino acid requirements based on isotopic techniques}

In the last 20 years, technological advances in massspectrometry have made it possible to explore aspects of basic and applied nutrition in vivo that were otherwise impossible to assess. These isotopic methods have facilitated a dynamic approach to determining amino acid requirements in humans through the infusion of amino acid tracers, ingestion of single amino acid-labeled protein or uniformly labeled proteins ${ }^{(11)}$. In general, the determination of amino acid requirements involves the feeding of graded amounts of the test amino acid and measuring the relevant biological outcomes. If the kinetics of a specific amino acid (such as leucine) can be measured with reasonable certainty, then the oxidation of leucine, measured over a day, would represent its irreversible loss that would need to be replaced by dietary intake, and hence, its daily requirement ${ }^{(12,13)}$. A leucine balance could be constructed, such that it could be plotted as an outcome against different leucine intakes to find the intake at which the balance was neutral (Fig 1). These developments in tracer methods really meant that one could measure the requirements of leucine with some certainty. However, could the requirement of the other IAA be independently and experimentally confirmed? The key problem was in the measurement of the precursor pool of the tracer amino acid, since this was critical to the measurement of the amino acid oxidation.

A more recent technique (that had its roots in earlier animal experiments) that really broke the impass in experimentally measuring the requirements for all the other IAA was the indicator amino acid oxidation technique (IAAO). The IAAO method is a functional method based on the concept that the amount of the limiting amino acid governs the partition of the other IAA between retention for protein synthesis or oxidation $^{(14)}$. In this method, the test amino acid and the tracer amino acid are different, such that the behaviour of the tracer oxidation and balance under different test amino acid intakes determines (or indicates) the test amino acid requirement. In this approach, the oxidation and balance data of the indicator amino acid (whose intake is held constant) at different test amino acid intakes can be analyzed to yield a breakpoint of a plateau in indicator amino acid oxidation (IAAO), or a zero balance (IAAB), which indicates the requirement of the test amino acid (Fig 1). This is because at suboptimal (limiting) intakes of the test amino acid, protein synthesis is 'frustrated' leading to increased oxidation of the other dietary IAA's. At intakes of the test amino acid that are optimal or above the requirement, the indicator amino acid oxidation would plateau off at its lowest level, and its balance would come to zero (Fig 1). In general, the technical problems of precursor pool identification that are related to the DAAO/ DAAB method are not present, since the indicator chosen is one in which the precursor pool is known and/or validated. This method is either applied as a short term IAAO method ${ }^{(15)}$ or a longer-term $24 \mathrm{~h}$ IAAO and IAAB method ${ }^{(12)}$. The requirement is taken as the intake of amino acid that provides for an inflection (or breakpoint) in the pattern of the indicator amino acid oxidation or balance response to different test amino acid intakes.

The short term IAAO method has been used with lysine or phenylalanine as the indicator amino $\operatorname{acid}^{(16,17)}$, where the appearance of the ${ }^{13} \mathrm{C}$ label (from the labeled amino acid) in the breath is measured in the fed state over a few hours. Importantly, these studies are conducted with a short $(48 \mathrm{~h})$ dietary adaptation period. Therefore, the relative ease, the short dietary adaptation and the relatively non-invasive

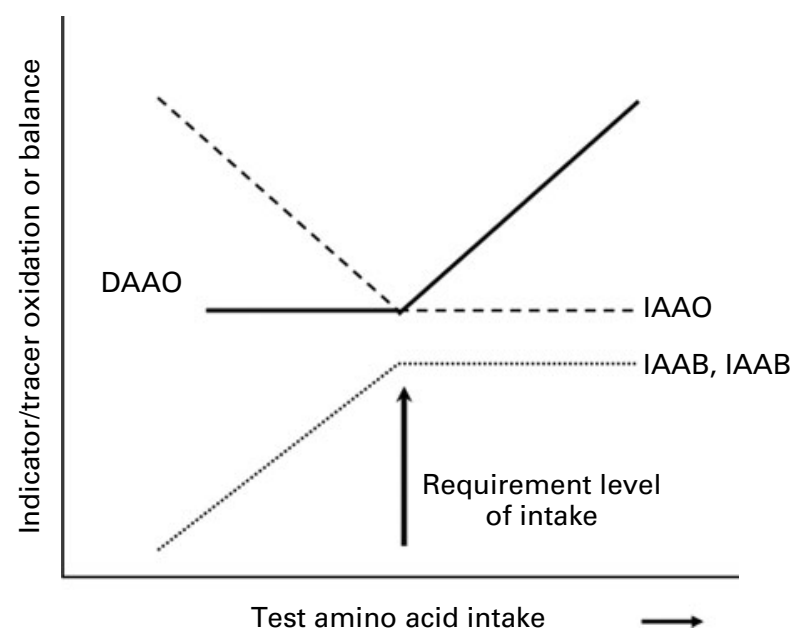

Fig. 1. Inflection or breakpoint on all lines indicates the measured requirement level. Solid line: DAAO - Increasing oxidation of 'test' amino acid at supra-maintenance test amino acid intake levels. Large dashed line: IAAO - Decreasing oxidation of 'indicator' amino acid at supra-maintenance test amino acid intake levels. Small dashed line: DAAB or IAAB - Increasing balance towards zero balance of either 'test' or 'indicator' amino acid balance with increasing test amino acid intake levels. Note that at supra-maintenance intake levels, balance stays at zero. 
Table 4. Estimation of IAA requirements by the factorial approach and IAAO method for school age children

\begin{tabular}{|c|c|c|c|}
\hline \multirow[b]{2}{*}{ Amino acid } & Factorial approach & IAAO Approach & \multirow[b]{2}{*}{ Reference } \\
\hline & \multicolumn{2}{|c|}{ (mg/kg/day) } & \\
\hline \multirow[t]{2}{*}{ Lysine } & 35 & 33.5 & 24 \\
\hline & & 35 & 23 \\
\hline Methionine & 18 & $12 \cdot 9$ * & 26 \\
\hline $\begin{array}{l}\text { Total BCAA } \\
\text { (Isoleucine } \\
\text { + leucine } \\
\text { + valine) }\end{array}$ & 96 & 147 & 25 \\
\hline
\end{tabular}

* With no cysteine, total SAA

nature of experimentation, is a strength that allows for many experiments at different levels of test amino acid intake, to be carried out on the same subject which in turn allows for the measurement of the variance of the requirement estimate for each amino acid. The non-invasiveness of the technique has been further advanced, in that the tracer can be administered orally and urine can be used to determine the equivalent enrichment of the tracer amino acid in its precursor pool $^{(18-21)}$. On the other hand, the lack of a sufficient dietary adaptation period, the lack of a fasted state measurement, and the short-term nature of the fed state evaluation may or may not influence the result for the determined amino acid requirement, and there is insufficient evidence available at present to make a judgement about this. In one study that measured the requirement of valine in adults, using both a $24 \mathrm{~h}$ IAAB method as well as the short term fed state IAAO method, after 7 days of adaptation to the test diet, both methods gave similar estimates of the requirement ${ }^{(22)}$.

Over the last decade, dietary IAA requirements have been determined by using the IAAO method in healthy school age children in Canada and India ${ }^{(23-26)}$, as well as children recovering from severe undernutrition ${ }^{(27)}$ and in moderately undernourished children with intestinal infestations (Pillai et al, unpublished). The determined amino acid requirements for branched chain amino acids, sulphur containing amino acids and lysine are shown in Table 4 with the comparisons to current $\mathrm{WHO} / \mathrm{FAO} / \mathrm{UNU}^{(7)}$ values. In general, the results of the isotopic experimental method are similar to those derived by the factorial method, except for the BCAA. In addition, the estimates appear to be similar across geographical regions, indicating that adaptation to lower or different food based protein intakes may not lower specific IAA requirements. For example, the mean daily requirement of lysine was determined to be $33.5 \mathrm{mg} / \mathrm{kg} / \mathrm{d}$ in an Indian study on local normally nourished children, which was similar to that of Canadian children $(35 \mathrm{mg} / \mathrm{kg} / \mathrm{d})$, determined by the same method ${ }^{(23)}$. However, the Canadian children were about $3 \%$ and $18 \%$ taller and heavier respectively, with a $1.5 \%$ greater body fat percentage than Indian children. Therefore, the similar lysine requirements resulting from these studies in two geographically and socio-economically distinct regions support the current factorially based $\mathrm{WHO} / \mathrm{FAO} / \mathrm{UNU}^{(7)}$ lysine recommendation of $35 \mathrm{mg} / \mathrm{kg} / \mathrm{d}$ for children aged $3-10 \mathrm{y}$. This is not altogether surprising, since similar results have been found for several dietary IAA such as lysine, leucine, methionine, and threonine in adults, where their daily estimated requirements in Indian adults are similar to those in Western populations $^{(13,28-30)}$.

The key question is whether or not to include a growth requirement into these estimates, that is, to layer a factorial estimate for growth over these experimentally based requirement figures. In the Indian study, the children grew by about $0.5 \mathrm{~cm}$ over the study period ( 7 weeks); this is some $30 \%$ less than what would be predicted by the $50^{\text {th }}$ percentile of the NCHS growth standard for the mean age of the study participants $^{(31)}$. In our opinion, the lysine requirement of this sub-optimal growth will be captured within the IAAO model. However, it is likely that a greater or optimal rate of growth would require a greater amount of dietary IAA. Clearly then, the best estimate of the optimal daily lysine requirement would be that measured in optimally growing children. It is possible to speculate on this requirement. If the study children were growing at $70 \%$ of the optimal rate, then, based on the factorial method for estimating growth requirements in this age of child $^{(7)}$, it is likely that they would require about $2 \mathrm{mg} / \mathrm{kg} / \mathrm{d}$ in addition to the measured requirement. Further, it is relevant to consider the effects that catch up growth, or infections and parasites can have on the requirement. From the environment viewpoint, we earlier reported that the daily lysine requirement was increased by about $50 \%$ in chronically undernourished men who lived in poor environments ${ }^{(32)}$. Part of this increased requirement was due to the effects of intestinal parasites ${ }^{(33)}$. It is also possible that subclinical infections could increase the daily dietary IAA requirement through increased amino acid oxidation ${ }^{(34)}$. Therefore, further direct studies on the lysine requirements of undernourished or sub-clinically infected children, or on those children exhibiting catch up growth, are necessary. In principle, while the amino acid requirement for catch up growth may increase the overall requirements, it is also possible that the efficiency of tissue deposition during catch up growth may increase. Therefore the prediction of these, based on a factorial method, may be confounded, and experimental evidence is necessary for informed decision making.

The short term IAAO method has also been used in innovative ways to determine other metabolic indices. Most recently, the requirement for tyrosine during the rapid catch-up in body weight related to the recovery from severe childhood undernutrition was found to be $99 \mathrm{mg} / \mathrm{kg} / \mathrm{d}$ when the children were growing at about $15 \mathrm{~g} / \mathrm{kg} / \mathrm{d}^{(25)}$. Further, the IAAO

Table 5. Dietary IAA requirement estimates in adults (WHO/FAO/UNU, 2007)

\section{Amino acid}

Value $(\mathrm{mg} / \mathrm{kg} /$ day)

\section{Leucine} 39

Lysine

Threonine

Phenylalanine + Tyrosine

Tryptophan

Methionine + cysteine

Valine

Isoleucine 
method has been adapted to determine protein requirements in adults, although this procedure still needs validation ${ }^{(35)}$. This method has also been recently applied to determine the metabolic availability of sulphur amino acids (SAA) from casein versus a soya protein isolate using ${ }^{13} \mathrm{C}$ phenylalanine as an indictor ${ }^{(36)}$.

\section{Dietary IAA requirements of elderly people}

The data based on the currently acceptable methodologies described above are inadequate to make a separate recommendation for dietary IAA requirements in elderly people. Where available, the results of the $\mathrm{N}$ balance and tracer-based approaches are fragmentary and conflicting. However, the only available data on amino acid requirements in the elderly concern sulphur amino acids, and showed the same total requirement as that set for young subjects but with a reduced sparing effect of cysteine on methionine ${ }^{(37)}$. Therefore, it is recommended that the dietary IAA requirement pattern for elderly people be taken as the same as that for adults (Table 5). Furthermore, there is as yet no convincing evidence that the elderly require more dietary protein, and while some reviews have suggested that there may be a slightly higher requirement for protein $^{(38)}$, recent studies do not support this ${ }^{(39)}$.

\section{Summary}

While there are assumptions and complexities in the factorial method, this is presently the only method that has been used to determine children's IAA requirements, while at the same time considering their normal growth as well. The minimally invasive IAAO method has made it possible to begin a series of experimental determinations of the dietary IAA requirements of children, and these appear to bear out predictions made by the factorial method. Key questions remain about how to account for the requirements for optimal or catch up growth, particularly in developing country populations. There are not enough data or convincing evidence to consider a different dietary IAA requirement pattern for the elderly versus the adult.

\section{Acknowledgements}

The authors declare that there are no conflicts of interest.

Both authors drafted, interpreted the data and critically reviewed the manuscript. Dr Kurpad is a consultant to the Kraft Health and Wellness Board; his remuneration for this activity goes entirely to charity.

\section{References}

1. Forbes GB (1973) Another source of error in the metabolic balance method. Nutr Rev 31, 297-300.

2. Hegsted DM (1976) Balance studies. J Nutr 106, 307-311.

3. Young VR (1986) Nutritional balance studies: indicators of human requirements or of adaptive mechanisms? J Nutr 116, 700-703.
4. Scrimshaw NS (1996) Criteria for valid nitrogen balance measurement of protein requirements. Eur J Clin Nutr 50, S196-S197.

5. Millward DJ (2001) Methodological considerations. Proc Nutr Soc 60, 3-5.

6. FAO (1985) Energy and protein requirements. Report of a joint FAO/WHO/UNU Expert Consultation. Geneva: WHO Technical Report Series no. 724. Geneva: WHO.

7. Joint WHO/FAO/UNU (2007) Protein and Amino Acid Requirements in Human Nutrition. Report of a Joint WHO/ FAO/UNU Expert Consultation, WHO Technical Report Series no. 935. Geneva: WHO

8. Ellis KJ, Shypailo RJ, Abrams SA, et al. (2000) The reference child and adolescent models of body composition. A contemporary comparison. Ann N Y Acad Sci 904, 374-382.

9. Butte NF, Hopkinson JM, Wong WW, et al. (2000) Body composition during the first 2 years of life: an updated reference. Pediatr Res $\mathbf{4 7}, 578-585$.

10. Davis TA, Nguyen HV, Garcia-Bravo R, et al. (1994) Amino acid composition of human milk is not unique. J Nutr 124, 1126-1132.

11. Bos C, Gaudichon C \& Tome D (2002) Isotopic studies of protein and amino acid requirements. Curr Opin in Clin Nut and Meta Care 5, 55-61.

12. Kurpad AV, Raj T, El-Khoury R, et al. (2001) The daily requirement for and splanchnic uptake of leucine in healthy adult healthy Indian subjects. Am J Clin Nutr 74, 747-755.

13. Kurpad AV, Regan MM, Raj T, et al. (2003) Leucine requirement and splanchnic uptake of leucine in chronically undernourished adult Indian subjects. Am J Clin Nutr 77, 861-867.

14. Elango R, Ball RO \& Pencharz PB (2008) Indicator amino acid oxidation: concept and application. J Nutr 138, 243-246.

15. Zello GA, Wykes LJ, Ball RO, et al. (1995) Recent advances in method of assessing dietary amino acid requirements for adult humans. J Nutr 125, 2907-2915.

16. Zello GA, Pencharz PB \& Ball RO (1993) Dietary lysine requirement of young adult males determined by oxidation of L- $\left[1-{ }^{13} \mathrm{C}\right]$ phenylalanine. Am J Physiol 264, E677-E685.

17. Roberts SB, Thorpe JM, Ball RO, et al. (2001) Tyrosine requirement of healthy men receiving a fixed phenylalanine intake determined by using indicator amino acid oxidation. Am J Clin Nutr 73, 276-282.

18. Bross R, Ball RO \& Pencharz PB (1998) Development of a minimally invasive protocol for the determination of phenylalanine and lysine kinetics in humans during the fed state. J Nutr 128, 1913-1919.

19. Lea F, Malvern PA, de Benoist B, et al. (1984) The measurement of whole body protein turnover in the preterm infant with intragastric infusion of L- $\left[1-{ }^{13} \mathrm{C}\right]$ leucine and sampling of the urinary leucine pool. Clin Sci (Lond) 66, 155-164.

20. Wykes LJ, Ball RO, Menendez CE, et al. (1990) Urine collection as an alternative to blood sampling: a noninvasive means of determining isotopic enrichment to study amino acid flux in neonates. Eur J Clin Nutr 44, 605-608.

21. Zello GA, Marai L, Tung AS, et al. (1994) Plasma and urine enrichments following infusion of $\mathrm{L}-\left[1-{ }^{13} \mathrm{C}\right]$ phenylalanine and $\mathrm{L}$-[ring- $\left.{ }^{2} \mathrm{H}_{5}\right]$ phenylalanine in humans: evidence for an isotope effect in renal tubular re absorption. Metab Clin Exp 43, 487-491.

22. Kurpad AV, Regan MM, Raj T, et al. (2005) The daily valine requirement of healthy adult Indians determined by the 24-h indicator amino acid balance approach. Am J Clin Nutr 82, 373-379.

23. Elango R, Humayun MA, Ball RO, et al. (2007) Lysine requirement of healthy school-age children determined by 
the indicator amino acid oxidation method. Am J Clin Nutr 86, 360-365.

24. Pillai RR, Elango R, Muthayya S, et al. (2010) Lysine requirement of healthy, school-aged Indian children determined by the indicator amino acid oxidation technique. $J$ Nutr 140, $54-59$.

25. Mager DR, Wykes LJ, Ball RO, et al. (2003) Branchedchain amino acid requirements in school-aged children determined by indicator amino acid oxidation (IAAO). J Nutr 133, 3540-3545.

26. Turner JM, Humayun MA, Elango R, et al. (2006) Total sulfur amino acid requirement of healthy school-age children as determined by indicator amino acid oxidation technique. Am J Clin Nutr 83, 619-623.

27. Badaloo A, Jean WC, Hsu, et al. (2010) Tyrosine requirement during the rapid catch-up growth phase of recovery from severe childhood under nutrition. Br J Nutr 104, 1174-1180.

28. Kurpad AV, Raj T, El-Khoury A, et al. (2001) Lysine requirements of healthy adult Indian subjects, measured by indicator amino acid balance technique. Am J Clin Nutr 73, 900-907.

29. Kurpad AV, Regan MM, Varalaksmi S, et al. (2003) Daily methionine requirements of healthy Indian men, measured by a 24-h indicator amino acid oxidation and balance technique. Am J Clin Nutr 77, 1198-1205.

30. Kurpad AV, Raj T, Regan MM, et al (2002) Threonine requirements of healthy Indian adults, measured by a $24 \mathrm{~h}$ indicator amino acid oxidation and balance technique. Am J Clin Nutr 76, 789-797.

31. Hamill PVV, Drizid TA, Johnson CL, et al. (1979) Physical growth: National Center for Health Statistics percentiles. Am J Clin Nutr 32, 607-629.
32. Kurpad AV, Regan MM, Raj T, et al. (2003) Vasudevan J. (2003) Kuriyan R, Gnanou J, Young VR. Lysine requirements of chronically undernourished adult Indian men, measured by a $24-\mathrm{h}$ indicator amino acid oxidation and balance technique. Am J Clin Nutr 77, 101-108.

33. Kurpad AV, Regan MM, Nazareth D, et al. (2003) Nagaraj S, Gnanou J, Young VR. Intestinal parasites increase the dietary lysine requirement in chronically undernourished Indian men. Am J Clin Nutr 78, 1145-1151.

34. Reeds PJ, Fjeld CR \& Jahoor F (1994) Do the differences in the amino acid composition of acute phase and muscle proteins have a bearing on nitrogen loss in traumatic states? J Nutr 124, 906-910.

35. Humayun MA, Elango R, Ball RO, et al. (2007) Re-evaluation of the protein requirement in young men with the indicator amino acid oxidation technique. Am J Clin Nutr 86, 995-1002.

36. Humayun MA, Elango R, Moehn S, et al. (2007) Application of the indicator amino acid oxidation technique for the determination of metabolic availability of sulfur amino acid from casein versus soy protein isolate in adult men. $J$ Nutr 137, 1874-1879.

37. Fukagawa NK, Yu YM \& Young VR (1998) Methionine and cysteine kinetics at different intakes of methionine and cysteine in elderly men and women. Am J Clin Nutr $\mathbf{6 8}$, 380-388

38. Kurpad AV \& Vaz M (2000) Protein and amino acid requirements of elderly human subjects. Eur J Clin Nutr $\mathbf{5 4}$ S131-S142.

39. Campbell WW, Johnson CA, McCabe GP, et al (2008) Dietary protein requirements of younger and older adults. Am J Clin Nutr 88, 1322-1329. 